\title{
Altazor: Entierros y Comienzos
}

Altazor morirás. Se secarả tu voz y serás invisible

La Tierra seguitá girando sobre su órbita precisa

Temerosa de un traspié como el equilibrado sobre el alambre que ata las miradas de pavor (p. 369) ${ }^{1}$

Así como Zaratustra señala la muerte de dios, Huidobro anuncia la desaparición del superhombre-poeta que él había tratado de inventar y encarnar. A lo largo de los siete cantos de Altazor se va desbaratando de modos contradictorios y complejos, la ficción de un yo individual, de la subjetividad creadora. Altazor viaja en un paracaidas que lo lleva inevitablemente hacia abajo. El espacio, estrechamente ligado a la obra de Huidobro ("la poesía es un atentado celeste", decía el creacionista con fe en las palabras) se convierte en una nada rechazante, amenazadora. Altazor cae del espacio en el espacio y de sí mismo en lo desconocido:

\section{Cae}

Cae eternamente

Cae al fondo del infinito

Cae al fondo de ti mismo

Cae lo más bajo que se pueda caer

(p. 369)

Vivir es precisamente caída, autodestrucción. ¿Pero, qué es lo destruido? Precisamente ahí radica la novedad de Altazor en la obra de Huidobro. Las virtudes atribuidas a lo que llegó a llamar la superlucidez ${ }^{2}$ (hablando a propósito del surrealismo en contra de la escritura automá-

1 La paginación corresponde a: Vicente Huidobro, Obras completas (Santiago de Chile: Zig-Zag, 1964), T. 1 .

2 Ver sus manifiestos, en la edición ya citada. De esa lectura se desprende una teoría del poeta como dueño de una inteligencia y lucidez que podrían llegar a imitar la capacidad creadora de la Naturaleza. 
tica, la literatura de los locos, etc.), la creación de mundos autónomos con la palabra, la invención de una literatura que progresaría como la ciencia, todo eso se desmorona y transforma. Altazor es un poema que, volcado sobre si mismo, se interroga acerca de su valor, se desdice y cuestiona. En la dinámica del texto, la muerte de Altazor es también el fin del inventor de mundos, la crítica al creador esperanzado en su singularidad:

Más débil marcho con mis ansias

Que un ejército sin luz en medio de emboscadas

Por otra parte, se borra la ilusión de la existencia de un individuo que piense y actúe coherentemente, capaz de dirigirse hacia un fin único: el hombre es un tejido de relaciones, una madeja autoconsciente:

Flor de contradicciones bailando un fox-trot Paradoja fatal

Gran parte de la tensión de Altazor surge de la eficacia y profundidad con que el poema, al volverse sobre sí e interrogarse sobre su naturaleza, abre nuevas puertas, insinúa caminos que permiten que el lector construya varios textos posibles. Uno de ellos sugiere al poeta como testigo de una realidad exterior natural y hasta a ratos social:

Y mientras los astros y las olas tengan algo que decir Será por mi boca que hablarán a los hombres.

Esta dirección se vio concretada posteriormente en la obra de Huidobro: en Ver y palpar (el título ya indica un cambio radical con respecto al creacionismo), El ciudadano del olvido y algunos de los Ultimos poemas,

Se insinúa también otra lectura del poema: como crónica de la búsqueda de "una música del espíritu". Pero, ¿a qué alude ese "espíritu"? Se trata, aparentemente, de un yo impersonal encarnado en la palabra pura. Los Cantos VII, IV y V son ejemplos de este intento. Están construidos por juegos de palabras cuyas funciones difieren entre sí. El VII es una desintegración del lenguaje que expresa el carácter aún inaca- 
bado de la búsqueda, la impotencia ante la necesidad de encontrar la "música del espíritu". En el IV:

Ya viene la golondrina

$Y a$ viene la golonfina

Ya viene la golontrina

$Y a$ viene la goloncima

$Y a$ viene la golonchina

(pp. 398-9)

las palabras conservan su significado, se trata de combinaciones muy ingeniosas donde los vocablos no pierden su valor tradicional de referentes pero van adquiriendo ottos mediante asociaciones que dan resultados inusitados. En el V, al culminar el juego a propósito de molino, hay una alusión deliberada a la música: "La carabantantina", etc. (p. 414). No es aún la "música del espíritu" cuya búsqueda, en un gesto de obvias resonancias románticas, había comenzado a preocupar al Huidobro de esta época. Es imitación musical, dependencia con respecto a un dominio artístico extraliterario. Entre esta búsqueda de una "música del espíritu" y el tránsito del poeta creacionista al testigo existe una estrecha relación. En ambos casos se trata de alternativas que proponen a la poesía como explicitación de una realidad preexistente. En "La creación pura", Huidobro hace suya una frase de Schleiermacher: "El arte y la poesía sólo expresan la verdad de la conciencia singular" y agrega que esta verdad nada tiene en común con la verdad objetiva. Altazor problematiza y niega estas afirmaciones: el arte ya no es la realización de la conciencia singular sino una práctica cuyas características se intuyen de modos contradictorios en el poema. La confianza en el universo artístico, la actitud triunfante del poeta que quiere fabricar entes nuevos imitando a la naturaleza en su potencia creadora, desemboca, irónicamente en caminos que hemos entrevisto. De este modo, Altazor, el poema que muestra a un Huidobro maduro en posesión de un rico lenguaje creacionista, vive negando los fundamentos que lo construyen, cuestionándose y burlándose de la poesía:

Basta señora arpa de las bellas imágenes

De los furtivos como iluminados

Otra cosa otra cosa buscamos

El plural del "buscamos" indica ya el grado de autocrítica y lucidez que la poesia de Huidobro alcanza en Altazor. Negación de la indivi- 
dualidad del artista, inclusión del lector en la construcción del texto, imprecisión de los objetivos del poema, replegado sobre sí para interrogarse sobre su propio sentido.

La conclusión más obvia es ver a un Huidobro anti-creacionista rechazando en su obra poética principios que defendió hasta el final de su vida en otros escritos. ${ }^{3}$ Pero existe otra dimensión en la lectura de este gesto irónico con respecto al poema. Altazor es un entierro de la poesía hispanoamericana del Modernismo al Creacionismo. Es el fin de los cenáculos literarios, los manifiestos, la ilusión de que la poesía tiene objetivos unívocos. Se celebra la muerte del poeta hacedor de mundos, de músicas. La negatividad del gesto de Altazor abraza, así, las ilusiones de Darío, Martí, Lugones y tantos otros. Huidobro señala que el objetivo de la poesía es buscar "otra cosa". Y acaso no sea demasiado desatinado notar que desde Huidobro la poesia hispanoamericana se ha dedicado a definir e interrogarse sobre esa "otra cosa". Huidobro, el doble de sí mismo en Altazor, anunció su propia caída y entrevió las preguntas del nuevo comienzo.

ALICIA BORINSKY

The Jobns Hopkins University

3 Es de notar que Huidobro no escribió manifiestos críticos de su Creacionismo. Su obra poética, en ese sentido, revela una mayor madurez que su prosa teórica acerca de literatura. 